Jurnal Pendidikan Matematika : Judika Education

Volume 1, Nomor 2, Juli-Desember 2018

e-ISSN : 2614-6088

p-ISSN : 2620-732X

DOI: https://doi.org/10.31539/judika.v1i2.412

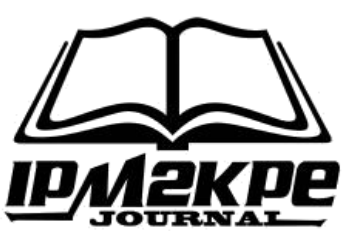

\title{
PENGEMBANGAN LEMBAR KERJA SISWA (LKS) \\ BERBASIS PROBLEM BASED LEARNING \\ UNTUK MENINGKATKAN KEMAMPUAN PENALARAN MATEMATIKA
}

\author{
Sri Handayani ${ }^{1}$, Novianti Mandasari ${ }^{2}$ \\ STKIP PGRI Lubuklinggau ${ }^{1,2}$ \\ srihandayanimath@gmail.com ${ }^{1}$
}

\begin{abstract}
ABSTRAK
Tujuan penelitian ini adalah untuk menghasilkan lembar kerja siswa berbasis Problem Based Learning (PBL) yang valid dan praktis untuk siswa sekolah menengah Pertama Kota Lubuklinggau. Penelitian ini merupakan penelitian pengembangan atau development research tipe formative research. Subjek penelitian adalah siswa SMP Negeri di Kota Lubulinggau, yang berjumlah 75 orang, 27 orang dari SMP N 9 Lubuklinggau, 27 orang dari SMP N 11 Lubuklinggau, dan 21 orang dari SMP PGRI Lubuklinggau. Teknik pengumpulan data yang digunakan adalah walk through, untuk mengetahui validitas lembar kerja siswa secara konten, konstruk dan bahasa serta dokumen untuk mengetahui kepraktisan lembar kerja siswa. Penelitian ini menghasilkan Lembar Kerja Siswa (LKS) berbasis problem based learning yang dapat mengukur kemampuan penalaran matematika siswa. Hasil tes secara keseluruhan dengan nilai rata-rata kemampuan penalaran matematika mencapai 70,15 dinyatakan baik. Simpulan, Lembar Kerja Siswa yang dikembangkan valid dan praktis untuk digunakan serta memiliki efek potensial terhadap peningkatan kemampuan penalaran matematika siswa.
\end{abstract}

Kata Kunci : Kemampuan Penalaran Matematika, LKS, Problem Based Learning.

\begin{abstract}
The purpose of this study was to produce a valid and practical Problem Based Learning (PBL) based student worksheet for junior high school students in Lubuklinggau. This research is a development research or development research type formative research. The subjects of the study were 75 State Junior High School students in Lubulinggau City, 27 people from SMP N 9 Lubuklinggau, 27 people from SMP N 11 Lubuklinggau, and 21 people from SMP PGRI Lubuklinggau. Data collection techniques used are walk through, to determine the validity of student worksheets in content, construct and language as well as documents to determine the practicality of student worksheets. This research produces Problem Based Learning based student worksheets that can measure students' mathematical reasoning abilities. Overall test results with an average value of 70,15 mathematical reasoning ability stated good. Conclusions, Student
\end{abstract}


Worksheets developed are valid and practical to use and have a potential effect on improving students' mathematical reasoning abilities.

Keywords: Mathematical Reasoning Ability, LKS, Problem Based Learning.

\section{PENDAHULUAN}

Matematika merupakan salah satu komponen dari serangkaian mata pelajaran yang mempunyai peran penting dalam pendidikan (Sundayana, 2013). Seperti halnya pendapat Sutjipto (Yuhasriati, 2012) yang menyatakan bahwa matematika merupakan salah satu pelajaran yang penting dikuasai di sekolah karena banyak kegunaannya dalam kehiduan sehar-hari. Mengingat pentingnya mata pelajaran matematika, maka matematika diberikan disemua jenjang pendidikan, mulai dari sekolah dasar sampai perguruan tinggi.

Pelajaran matematika juga merupakan salah satu ilmu yang diwajiban dalam ujian nasional (UN), sehingga siswa diwajibkan mempelajari matematika. Berdasarkan kenyataan kemampuan kognitif asingmasing siswa berbeda-beda tentunya peran guru dan penggunaan media pembelajaran yang iovatif dan kreatif sangat diperlukan untuk mendapatkan kemampuan penerimaan dan penyerapan pelajaran matematika sesuai harapan.

Salah satu media pembelajaran yang dapat digunakan untuk meningkatkankemampuan penyerapan dan penerimaan materi matematika adalah Lembar Kerja Siswa sehingga siswa mampu dalam menyelasaikan masalah-masalah matematika yang berhubungan dengan dunia nyata.
Salah satu model pembelajaranyang dalam penerpannya menggunakan permasahan didunia nyata adalah model Problem Based Learning.

Yamin (2012) mengemukakan bahwa Problem Based Learning merupakan salah satu model pembelajaran inovatif yang memberikan kondisi belajar aktif kepada peserta didik dalam kondisi dunia nyata. Selain itu Riyanto (2012) berpendapat bahwa Problem Based Learning atau pembelajaran beradasarkan masalah adalah suatu model pembelajaran yang dirancang dan dikembangkan untuk mengembangan kemampuan peserta didik dalam menyelesaikan masalah.

Menurut Sugiyono (2010) Problem Based Learning ditandai oleh siswa yang bekerja berpasangan atau dalam kelompok-kelompok kecil untuk mengivestigasi masalah dunia nyata. Pembentukan suatu kelompokkelompok dalam proses belajar diharapkan dapat membantu siswa untuk memecahan masalah yang dihadapinya, serta dapat dengan mudah untuk memperoleh pengetahuan dan konsep yang dipelajarinya.

Maka dapat disimplkan Problem Based Learning merupakan model belajar dengan menyajikan suatu permasalahan yang menuntut siswa menginvestigasi masalah dan menyelesaikannya serta keterampilan 
berpartisipasi dalam tim. Beberapa Beberapa karakteristik pembelajaran berbasis masalah (Arends, 2008) yaitu sebagai berikut:

1. Pengajuan pertanyaan atau masalah Problem based learning mengorganisasikan pembelajaran di sekitar pertanyaan dan masalah yang kedua - duanya secara sosial penting dan secara pribadi bermakna untuk siswa. Masalah berkaitan dengan kehidupan nyata yang autentik, menghindari jawaban sederhana, dan memungkinkan adanya berbagai macam solusi untuk situasi itu.

2. Keterkaitan dengan disiplin ilmu lain masalah yang akan diselidiki dipilih dari situasi nyata agar dalam pemecahannya siswa mampu meninjau dari banyak mata pelajaran lainnya.

3. Menyelidiki masalah autentik. Problem based learning mengharuskan siswa melakukan penyelidikan autentik untuk mencari penyelesaian nyata. Siswa harus menganalisis dan mendefinisikan masalah, mengembangkan hipotesis, membuat ramalan, mengumpulkan dan menganalisa informasi, melakukan eksperimen (jika diperlukan), membuat inferensi, dan merumuskan kesimpulan,

4. Memamerkan hasil kerja. Problem based learning menuntut siswa untuk menghasilkan suatu produk tertentu dalam bentuk karya atau artefak dan peragaan yang mewakili bentuk penyelesaian masalah yang mereka temukan. Produk dapat berupa laporan, model fisik, video, maupun program komputer.

5. Kolaborasi. Problem based learning dicirikan oleh siswa yang bekerja sama satu sama lainnya, paling sering secara berpasangan atau dalam kelompok kecil. Trianto (2010) menyatakan bahwa bekerja sama memberikan motivasi untuk secara berkelanjutan terlibat dalam tugas-tugas kompleks dan memperbanyak peluang untuk berbagi inkuiri dan dialog dan untuk mengembangkan keterampilan sosial dan keterampilan berpikir.

Sedangkan langkah-langkah pembelajaran Problem Based Learning (Sani, 2014) adalah : Fase 1. Memberikan orientasi permasalahan kepada peserta didik (guru menyajikan permasalahan, membahas tujuan pembelajaran, memaparkan kebutuhan logistic untuk pembelajaran, memotivasi peserta didik untuk terlibat aktif), Fase 2. Mengorganisasikan peserta didik unuk penyelidikan (guru membantu peserta didik dalam mendefinisikan dan mengorganisasikan tugas-tugas/ penyelidikan untuk menyelesaikan permasalahan). Fase 3. Pelaksanaan investigasi (guru mendorong peserta didik untuk memperoleh informasi yang tepat, melaksanakan penyelidikan dan mencari penjelasan solusi), Fase 4. Mengembangkan dan menyajikan hasil (membantu siswa 
dalam merencanakan produk yang tepat dan relevan, seperti laporan, rekaman video dan sebagainya untuk keperluan penyampaian hasil). Fase 5.Menganalisi dan mengevaluasi proses penyelidikan (guru membantu peserta didik melakukan refleksi terhadap penyelidikan dan proses yang akan mereka lakukan).

Penggunaan model pembelajaran yang tepat jika tidak didukung dengan penggunaan media pembelajaran yang tepat juga maka tujuan pembelajaran tetap tidak akan mencapai hasil yang maksimal, salah satu media pembelajaran yang dapat digunakan untuk meningkatkan kemampuan penyerapan dan penerimaan materi matematika adalah Lembar Kerja Siswa (LKS). Lembar Kerja Siswa merupakan sala satu jenis alat bantu pembelajaran (Prastowo, 2012). Trianto (2010) menjelaskan bahwa LKS merupakan suatu bahan ajar cetak berupa lembaran berisi tugas yang didalamnya berisi petunjuk, langkah-langkah untuk menyelesaikan tugas.

LKS juga merupakan stimulus atau bimbingan guru dalam pembelajaran yang akan disajikan secara tertulis sehingga dalam penulisannya perlu memperhatikan kriteria media grafis sebagai media visual untuk menarik perhatian peserta didik (Pariske, 2012).

Alternatif tujuan pengemasan materi dalam bentuk LKS dalam panduan pelaksanaan materi pembelajaran adalah 1) LKS dapat membantu siswa dalam menemukan suatu konsep, 2) LKS dapat membantu siswa menerapkan dan mengintegrasikan beberapa konsep yang telah ditemukan, 3) LKS berfungsi sebagai penuntun belajar, 4) LKS berfungsi sebagai penguatan, 5) LKS berfungsi sebagai petunjuk praktikum.

Manfaat yang diperoleh dengan menggunakan LKS menurut Darmadjo (1992) adalah: 1) memudahkan guru dalam mengelola proses belajar, misalnya mengubah kondisi belajar dari suasana guru sentris menjadi siswa sentris, 2) membantu guru mengarahkan siswanya untuk dapat menemkan konsep-konsep melalui aktivitasnya sendiri atau dalam kelompok kerja, 3) dapat digunakan untuk mengembangkan keterampilan proses, mengembangkan sikap ilmiah serta membangkitkan minat siswa terhadap alam sekitarnya, 4) memudahkan guru memantau keberhaslan siswa untuk mencapai sasaran belajar.

\section{METODE PENELITIAN}

Penelitian ini merupakan penelitian pengembangan atau development research tipe formative research (Tessmer,1993; Zulkardi, 2002). Penelitian ini mengembangkan Lembar Kerja Siswa (LKS) berbasis problem based learning yang valid dan praktis dalam pembelajaran matematika untuk kelas VIII SMP. Penelitian ini dilakukan dalam dua tahap, yaitu tahap preliminary atau persiapan dan tahap formative evaluation. Tahap formative evaluation meliputi: 1) Self evaluation terdiri dari: a) analisis dan b) desain, 
2) Prototyping (validasi, evaluasi dan revisi) terdiri dari: a) expert review dan one-to-one, b) small group, dan 3) Field test.

\section{HASIL PENELITIAN}

Pelaksanaan penelitian yang telah diuraikan pada bab sebelumnya melalui dua tahap yaitu pleminary dan tahap formatif evaluation yang meliputi self evalution, expert reviews dan one-to-one (low resitence to revision) dan small group serta field test (hight resistence in revison).

\section{Tahap Pleminary}

Penelitian ini dilakukan di tiga Sekolah Menengah Pertama Kota Lubuklinggau yakni ini di SMP Negeri 9 Lubuklinggau, SMP Negeri 11 Lubuklinggau, dan SMP PGRI 3 Lubuklinggau untuk mengetahui kemampuan penalaran matematika siswa SMP Kota Lubuklinggau. Sebagai subjek penelitian dilakukan pada siswa kelas VIII SMP Kota Lubuklinggau.

Sebelum melakukan proses ujicoba LKS berbasis Problem Based Learning maka LKS tesebut divalidasi terlebih dahulu oleh para ahli berdasarkan konten, konstruk, dan bahasa.

\section{Tahap Formatif Evaluation \\ Self Evaluation}

1. Analisis. Dalam penelitian ini, berdasarkan saran dari validator LKS berbasis Problem Based Learning yang digunakan yaitu pada konten isi, kontruks dan bahasa, serta analisis kurikulum tingkat Sekolah Menengah Pertama pada tahap ini mengacu pada satuan pendidikan SMP Negeri 9 Lubuklinggau, SMP Negeri 11 Lubuklinggau, dan SMP PGRI 3 Lubuklinggau

2. Desain. Dalam penelitian ini, pendesainan yang dilakukan peneliti yaitu mengenai LKS berbasis Problem Based Learning ,kisi-kisi dan soal-soal kemampuan penalaran matematika Sekolah Menengah Pertama di tiga sekolah yaitu SMP Negeri 9 Lubuklinggau, SMP Negeri 11 Lubuklinggau, dan SMP PGRI 3 Lubuklinggau. Pada pendesainan LKS yang dibuat oleh peneliti meliputi tiga karakteristik yakni, konten, konstruk, dan bahasa.

3. Prototyping

a. Expert reviews. Pada tahap uji coba pakar ini disebut uji validitas. Produk yang didesain dilihat, dinilai, dan dievaluasi berdasarkan konten, konstruk dan bahasa. Saran-saran dari validator digunakan untuk merevisi desain LKS yang dibuat oleh peneliti.

b. One-to-one. Pada pelaksanaan penelitian di tahap ini Lembar Kerja Siswa (LKS) yang di ujicobakan kepada anak (oneto-one) bernama Agil Seprina, Uswatun Hasanah, Andes Taper Mego, yang merupakan siswa SMP N 9 Lubuklinggau yang memiliki kemampuan tinggi, sedang dan rendah. LKS juga diujicobakan kepada 
siswa SMP N 11 Lubuklinggau yang bernama Cindi Cantika, Rintan Anggraini, Amelia Joly Yolanda, dengan kemampuan tinggi, sedang, rendah. Ujicoba ini dilakukan untuk melihat kesulitan-kesulitan siswa yang mungkin terjadi ketika mengerjakan LKS berbasis Problem Based Laearning dalam pembelajaran.

Setelah belajar dengan menggunakan LKS berbasis Problem Based Laearning siswa diminta memberikan komentarnya. Beberapa siswa menyatakan bahwa ada beberapa soal yang susah untuk mereka kerjakan, kesusahan yg mereka alami dikarenakan mereka tidak begitu memahami permasakahan yang terdapat didalam soal, dan siswa mengalami kesusahan dalam menalar permasalahan yang terdapat di soal, maka disinilah tingkat kemampuan soal dalam menggali dan meningkatkan kemampuan penalaran matematis siswa.

c. Small Group

LKS berbasis Problem Based Laearning pada prototipe kedua diujicobakan pada small group kepada enam orang siswa SMP Negeri 9 Lubuklinggau yaitu, M. Okan, Dwi Sari, Stephanie Unafa Y, Anastasya Aisyah, Boby Suganda, Ulia Sari yang mempunyai kemampuan tinggi, sedang, dan rendah. Enam orang siswa SMP Negeri 11 Lubuklinggau yaitu M Doni Aprinaldi, Amelia Joty Yolanda, Uswatun Hasanah, Cindi Canyika, DIyo Saputra, Alkadi Saputra. Pada pelaksanaan tahap ini peneliti mengujicobakan LKS berbasis Problem Based Laearning dengan mengamati kegiatan siswa dalam pengerjaan LKS secara berkelompok. Selain itu juga peneliti bertanya kepada siswa mengenai kesulitankesulitan yang mereka hadapi dalam pengerjaan LKS berbasis Problem Based Laearning tersebut, guna untuk mengetahui kendala dan apakah soal perlu diperbaiki atau tidak oleh peneliti untuk tahap selanjutnya.

Setelah dilaksanakan ujicoba, hasil yang diperoleh pada saat ujicoba pada tahap one-to-one dengan ujicoba pada tahap small group siswa dalam pengerjaan LKS berbasis PBL, siswa tidak mengalami kesulitan dalam mengerjakan LKS tersebut, beberapa siswa menyatakan ada beberapa soal yang mereka menyatakan susah untuk dikerjakan, hal ini disebabkan siswa belum begitu memahami permasalahan yang terdapat di soal , yang menuntut tingkat penelaran siswa. Berdasarkan komentar tersebut peneliti menyimpulkan soal penalaran tetap akan dilampirkan dalam LKS karena 
soal tersebut digunakan untuk mengukur kemampuan penalaran matematika siswa,

\section{Field Test}

Pengembangan LKS berbasis problem based learning pada prototype ke III bertujuan untuk mengukur kemampuan penalaran matematika siswa sekolah menengah pertama kota lubuklinggau. Pada kegiatan field test LKS diujicobakan ke tiga sekolah yaiu SMP N 09 Lubuklinggau kelas VIII 3 yang berjumlah 27 siswa SMP N 11 Lubuklinggau kelas VIII 4 yang berjumlah 27 siswa dan SMP PGRI 3 kelas VIII lubuklinggau yang berjumlah 21 siswa. Proses Pelaksanaan Field Test pada setiap sekolah dilaksanakan selama dua hari dan selama 2 jam pelajaran, di SMP N 09 Lubuklinggau dilaksanakan pada tanggal 21 agustus 2018, di SMP N 11 Lubuklinggau dilaksanakan pada tanggal 23 agustus 2018, dan di SMP PGRI 3 Lubuklinggau dilaksanakan pada tanggal 27 agustus 2018. Saat kegiatan field test berlangsung peneliti berkomunikasi dengan siswa untuk mengetahui kesulitan dan kendala yang dihadapi siswa dalam proses mengerjakan LKS berbasis problem based learning serta kendala siswa dalam mengerjakan soal-soal penalaran matematika.

Selain itu tujuan dari pelaksanaan prototype ketiga ini, yaitu pada kegiatan field test yaitu untuk mengetahui bagaimana efek potensial soal matematika model PISA untuk mengukur kemampuan penalaran matematika di Sekolah Menengah Pertama di ketiga sekolah yang berada di Kota Lubuklinggau. Diantaranya sekolah yang dipilih yaitu SMP Negeri 9 Lubuklinggau, SMP Negeri 11 Lubuklinggau, dan SMP PGRI 3 Lubuklinggau. Untuk memperoleh data dalam pelaksanaan penelitian ini yaitu dengan cara memberikan ujicoba LKS berbasis problem based learning kepada siswa yang mana LKS tersebut telah divalidasi terlebih dahulu oleh para ahli. Kemudian LKS tersebut juga telah di ujicoba juga pada tahap oneto-one kepada tiga orang siswa yang memiliki kemampuan yang berbeda yaitu tinggi, sedang, dan rendah. Serta soal tersebut juga telah di ujicoba juga pada tahap small group kepada enam orang siswa. Pada pelaksanaan field test ini LKS yang diujicobakan kepada 75 siswa.

\section{PEMBAHASAN}

Dari hasil analisis data tes soal untuk mengukur kemampuan penalaran matematika siswa pada LKS berbasis Promblem based learning di SMP Negeri 9 Lubuklinggau dapat diketahui bahwa ada 2 siswa $(7,40 \%)$ yang termasuk dalam kategori memiliki kemampuan penalaran matematika yang sangat baik, ada 18 siswa $(66,66 \%)$ yang termasuk dalam kategori memiliki kemampuan penalaran matematika yang baik dan ada $7(25,92 \%)$ siswa yang termasuk dalam kategori memiliki kemampuan penalaran matematika yang cukup, di SMP Negeri 11 Lubuklinggau berdasarkan hasil analisis data tes 
kemampuan penalaran matematika siswa pada LKS berbasis Promblem based learning ada 2 siswa $(7,40 \%)$ yang termasuk dalam kategori memiliki kemampuan penalaran matematika yang sangat baik, ada 21 siswa $(77,77 \%)$ yang termasuk dalam kategori memiliki kemampuan penalaran matematika yang baik dan ada 4 siswa $(14,81 \%)$ yang termasuk dalam kategori memiliki kemampuan penalaran matematika yang cukup, sedangkan di SMP PGRI 3 Lubuklinggau berdasarkan hasil analisis data tes kemampuan penalaran matematika siswa pada LKS berbasis Promblem based learning ada 3 $(14,2 \%)$ siswa yang memiliki kemampuan penalaran matematika dalam kategori sangat baik, ada 12 siswa $(57,14 \%)$ memiliki kemampuan penalaran matematika dalam kategori baik, 6 siswa ( 28,57\%) memiliki kemampuan penalaran matematika dalam kategori cukup.

\section{SIMPULAN}

Berdasarkan hasil penelitian yang telah dilaksanakan dapat disimpulkan : 1) Prototype perangkat pembelajaran Lembar Kerja Siswa berbasis Problem Based Learning dikategorikan valid dan praktis, 2) Lembar Kerja Siswa yang dikembangkan memiliki efek potensial terhadap kemampuan penalaran matematika siswa.

\section{DAFTAR PUSTAKA}

Arends, R. (2008). Learning to Teach. Penerjemah: Helly Prajitno \&
Sri Mulyani. New York:

McGraw Hill Company.

DarModjo, \& Hendro. (1992).

Pendidikan IPA II. Jakarta :

Depdikbud

Pariske, I. (2012). Pengembangan Lembar Kerja Siswa Matemaika Berbasis masalah. FMIPAUN. 1 (1).

Prastowo, A. (2012). Panduan Kreatif Membuat Bahan Ajar Inovatif. Yogyakarta: Diva Press.

Riyanto, Y. (2012). Paradigma Baru Pembelajaran. Jakarta: Kencana.

Sani, R., A. (2014). Pembelajaran Siantifik untuk Implementasi Kurikulum 2013. Jakarta: PT Bumi Aksara.

Sugiyono. (2010). Metode Penelitian Pendidikan. Bandung : Alfabeta.

Sundayana, H.R. (2013). Media Pembelajaran

Matematika. Bandung: Alfabeta

Tessmer, M. (1993). Planning and Conducting Formative Evaluations . Philadelphia: Kogan Page.

Trianto. (2010). Model Pembelajaran Terpadu. Jakarta: Bumi Aksana.

Yamin, M. (2012). Desain Baru Pembelajaran Kontruktivistik. Jakarta: Referensi.

Yuhasriati. (2012). Pendekatan Realistik dalam Pembelajaran Matematika. Jurnal peluang, 1(1); 81-87.

Zulkardi. (2002). Formatif Evaluation : What, Why, When and How (On Line). Tersedia : http://www.geocities.com/zu $\underline{\text { kardi/books.html. Diakses }}$ tanggal 25 Maret 2016 